\title{
HIV, hepatitis B and C, and syphilis prevalence and coinfection among sex workers in Southern Brazil
}

\author{
Fabiana Schuelter-Trevisol[1],[2], Geisiane Custódio[ ${ }^{[3]}$, Ana Carolina Barreto da Silva ${ }^{[3]}$, \\ Mikely Byala de Oliveira ${ }^{[3]}$, Audrei Wolfart ${ }^{[3]}$ and Daisson José Treviso[ ${ }^{[1],[2]}$
}

[1]. Programa de Mestrado em Ciências da Saúde, Universidade do Sul de Santa Catarina. Tubarão, SC. [2]. Centro de Pesquisas Clínicas do Hospital Nossa Senhora da Conceição, Tubarão, SC. [3]. Curso de Medicina, Universidade do Sul de Santa Catarina. Tubarão, SC.

\begin{abstract}
Introduction: Sex workers (SWs) are vulnerable to HIV, hepatitis, and syphilis coinfection. Methods: A cross-sectional study was conducted in Tubarão, Laguna, and Imbituba, Southern Brazil. We surveyed 147 SWs using face-to-face interviews and blood sampling for serological evaluation. Results: Prevalence of hepatitis B (HBV) was 23.1\%, syphilis 19.7\%, hepatitis C (HCV) $8.8 \%$, and HIV 8.8\%. Of 13 HIV-infected patients, 3 were co-infected with HCV, 4 with syphilis, and 5 with HBV. Conclusions: SWs had high HIV infection rates, and coinfection with viral hepatitis and syphilis.
\end{abstract}

Keywords: HIV. Hepatitis. Syphilis.

Sexually transmitted diseases (STDs), including acquired immunodeficiency syndrome, are a serious public health problem with a large number of cases, disease progression, and a variety of social and economic impacts on more severely affected countries ${ }^{1}$.

Sexual transmission is currently responsible for most reported human immunodeficiency virus (HIV) infections ${ }^{2}$. Coinfection with HIV and hepatitis B virus (HBV) and/or hepatitis $\mathrm{C}$ virus (HCV) occurs in a considerable number of cases and can be explained by common routes of viral transmission, such as vertical infection, sexual transmission, intravenous drug use, and blood transfusion ${ }^{3}$. Syphilis is an ulcerative sexually transmitted infection (STI) that facilitates entry of infectious agents like $\mathrm{HIV}^{4}$.

According to the Ministry of Health, the prevalence of HIV infection in Brazil is high among vulnerable populations, which includes sex workers (SWs), especially women $(5.1 \%)^{2}$.

Surveys conducted in Brazil and elsewhere have shown that SWs report low adherence to condom use and concomitant unsafe sexual practices, involvement with illicit drugs, a high prevalence of STDs, and other poor living conditions that increase the risk of disease transmission. Moreover, it difficult to monitor this population, which is constantly in flux ${ }^{5,6}$.

The aim of this study was to determine the coinfection and prevalence rates of HIV, HBV, and HCV, and syphilis among SWs in 3 selected cities in Southern Santa Catarina, Brazil.

Address to: Dria Fabiana Schuelter-Trevisol. Av. José Acácio Moreira 787, Bairro Dehon, 88704-900 Tubarão, SC, Brasil.

Phone: 5548 3622-1442; 5548 3631-7239

e-mail: fabiana.trevisol@unisul.br; fastrevisol@gmail.com

Received 29 Septermber 2011

Accepted 9 December 2011
This study was approved by the Research Ethics Committee of the University of Southern Santa Catarina.

Cross-sectional epidemiological study: We surveyed male, female, and transgender SWs in Tubarão, Laguna, and Imbituba in Southern Santa Catarina in 2009. Consenting subjects, aged 18 years or older, were included in the study.

Sex workers were contacted at work or at home through intermediaries from Nongovernmental Organizations (NGOs) and the Municipal Health Secretariats of the selected cities. The individuals who were recruited to participate in the study made up a convenience sample of all SWs encountered in their working places. Due to the high rates of transience among these individuals, there were no estimates of the total number of SWs working in the surveyed cities.

After informed consent was obtained, a semi-structured questionnaire was administered to collect the data of interest, including socio-demographic status, sexual habits, and other factors associated with STD transmission.

Blood samples were collected for serological testing. The serum was sent to a laboratory (Laboratório de Análises Clínicas da $20^{a}$ Gerência Estadual de Saúde do Estado de Santa Catarina) for HIV antibody detection. If there was a positive sample, it was sent to the Public Health Laboratory (LACEN$\mathrm{SC})$ to confirm the diagnosis.

Serological tests for detection of HBV, HCV, and syphilis were performed in a partnership with the Heath Secretariat of São Paulo State and Emilio Ribas Institute.

Tests for anti-HCV and HBV markers including hepatitis B surface antigen ( $\mathrm{HBsAg}$ ) and anti-hepatitis B core total (anti-HBc) were performed by enzyme immunoassay. For laboratory diagnosis of syphilis, enzyme immunoassay and venereal disease research laboratory (VDRL) screening tests were performed. When VDRL tests were positive, the Fluorescent Treponemal Antibody Absorbed Test (FTA-Abs) 
(indirect immunofluorescence) was used for confirmation. Treponema pallidum hemagglutination test (TPHA), an indirect hemagglutination test, was performed in case of divergence in the results.

The case definition for HIV infection followed Ordinance 59 of the Brazilian Ministry of Health, i.e., a sample reactive to enzyme immunoassay screening with confirmation by indirect immunofluorescence or western blot. Testing for HCV RNA was not available and we considered individuals who showed the presence of anti-HCV infected with hepatitis $\mathrm{C}$. Individuals positive for anti-HBc total or $\mathrm{HBsAg}$ were considered infected with hepatitis $\mathrm{B}$, and the presence of $\mathrm{HBsAg}$ was considered a marker of active infection, regardless of the total anti-HBc test result, with the presence of anti-HBc alone a marker of past infection. Syphilis was defined by reactive VDRL and enzyme immunoassay, with FTA-Abs confirmation.

The test results were reported to the participants with the mediation of the involved NGOs and municipal public health departments. Sero-positive subjects were referred to Unified Health System units that provide specialized medical care for infectious diseases.

The data collected were entered into EpiData version 3.1, and Statistical Package for the Social Sciences SPSS v. 16 was used for statistical analysis. Pearson's Chi-squared and Fisher's exact tests were used to examine the statistical differences in the distribution of variables between the groups. We surveyed $147 \mathrm{SWs}$, including 134 (91.2\%) women, $6(4.5 \%)$ men, and $7(4.3 \%)$ transgender individuals. Mean age was $28 \pm 9$ years, ranging between 18 and 60. Sixty-five $(44.2 \%)$ had a stable relationship with a steady partner. A significant proportion (43.7\%) had no fixed abode and moved between different cities and states engaged in migratory activities. The average monthly income was around $2 \times$ minimum wage, which was Brazilian real (BRL) 465 during the study period.

Sexual habits were predominantly heterosexual (78.2\%), followed by bisexual (17\%), and homosexual (4.8\%). Out of these, $28.6 \%$ engaged in anal sex. The median number of clients was 2 per day, ranging from 1 to 30 , and the median rate of sexual intercourse was 2 times per day, ranging from 1 to 15 . Among the study participants, $56.5 \%$ reported inhaling illicit drugs, $83.7 \%$ reported excessive alcohol consumption, and $1.4 \%$ reported injecting drugs.

The results showed that $8.8 \%$ of the participants surveyed had HIV infection, $8.8 \%$ had HCV, 23.1\% had HBV (active or past), and $19.7 \%$ had syphilis. With regard to HBV, 5 (3.4\%) of the participants were reactive to $\mathrm{HBsAg}, 3$ were also reactive to anti-HBc, and 2 were non-reactive to HBsAg. In all, anti-HBc seropositivity, which indicated past infection in the absence of HBsAg, was found in 32 (21.8\%) participants.

Table 1 shows the distribution of socio-demographic and behavioral characteristics of SWs, and seropositivity for HIV, HCV, HBV, and syphilis infections (Table 1).

Figure 1 shows the coinfection rates of the diseases investigated in this study. Each column represents the number of positive cases and coinfection with HIV, HBV, HCV, or syphilis (Figure 1).
Of the 13 HIV-infected patients, 3 (23\%) were coinfected with $\mathrm{HCV}, 4(30.8 \%)$ with syphilis, and 5 (38.5\%) with HBV. Among those infected with HCV, $3(23 \%)$ were also coinfected with HBV.

Of the 147 respondents, $8.8 \%$ had positive serology for HIV. A study conducted in Paranaguá, State of Paraná, showed $4.5 \%$ seroprevalence of HIV in 132 female SWs ${ }^{7}$. In 1996, the HIV infection rate among SWs in Brazil was approximately $18 \%$ according to the Ministry of Health. In the last survey conducted in 2010, the reported prevalence decreased to $5.1 \%{ }^{2}$. This decrease can be attributed to campaigns such as distribution of condoms and disposable syringes, access to screening and counseling centers, and public health care and treatment to reduce harm among vulnerable populations ${ }^{8}$. However, the HIV infection rate in this group is still much higher than in the general population ${ }^{2}$. The populations of the 3 surveyed cities amounted to 185,386 inhabitants, but since prostitution is not a registered occupation, and because SWs are usually moving frequently to different cities and states, it was difficult to establish the representativeness of the sample included in this study.

In this study, the HCV infection rate was $8.8 \%$ and the HBV rate was $23.1 \%$. In a study conducted in 6 different cities in Argentina, the infection rates were $14.4 \%$ for $\mathrm{HBV}, 4.3 \%$ for $\mathrm{HCV}$, and 3.2\% for $\mathrm{HIV}^{3}$. A study conducted in Montevideo, Uruguay, in a sample composed of 200 male transvestite SWs found that $50.5 \%$ had $\mathrm{HBV}$ infection, $6.5 \%$ had $\mathrm{HCV}$, and $21.5 \%$ had HIV ${ }^{9}$. These findings show that despite fluctuating percentages, SWs have a greater prevalence of hepatitis B and $\mathrm{C}$ infection than the general population.

In this study, from the total HIV-infected subjects, $38.5 \%$ had coinfection with HBV and $23 \%$ were coinfected with HCV. Coinfection of HIV and HBV and/or HCV is thought to be very common because of the similarity between the modes of disease transmission ${ }^{3,10}$.

Concerning sexual practices and risk behaviors, there was a high prevalence of HIV infection among male or transgender sex workers, and among those who had a longer time in prostitution, elevated frequency of sex per day, and practice

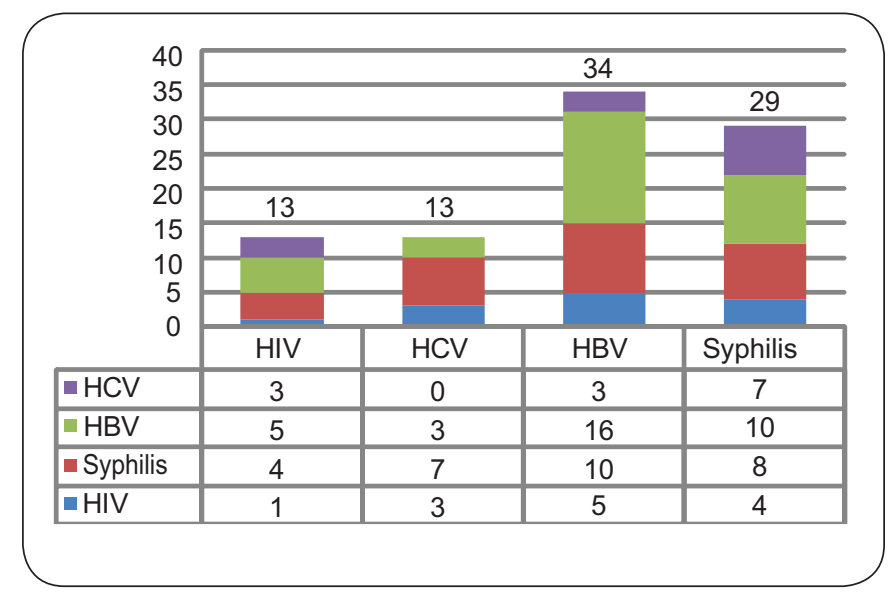

FIGURE 1 - HIV, HBV, HCV, and syphilis coinfection in sex workers. HCV: Hepatitis $\mathrm{C}$ virus; $\mathrm{HBV}$ : Hepatitis B virus, HIV: human immunodeficiency virus. 
TABLE 1 - Distribution of socio-demographic and behavioral characteristics of sex workers and seropositivity for HIV, HCV, HBV, and syphilis infections

\begin{tabular}{|c|c|c|c|c|c|c|c|c|c|}
\hline \multirow[b]{2}{*}{ Characteristic } & \multirow[b]{2}{*}{ Total } & \multicolumn{2}{|c|}{$\mathrm{HIV}+$} & \multicolumn{2}{|c|}{$\mathrm{HCV}+$} & \multicolumn{2}{|c|}{$\mathrm{HBV}+\S$} & \multicolumn{2}{|c|}{ Syphilis +} \\
\hline & & $\mathrm{n}$ & $\%$ & $\mathrm{n}$ & $\%$ & $\mathrm{n}$ & $\%$ & $\mathrm{n}$ & \\
\hline \multicolumn{10}{|l|}{ Age (years) } \\
\hline $18-24$ & 57 & 3 & 5.3 & 2 & 6.5 & 8 & 14.0 & 6 & 10 . \\
\hline $25-34$ & 59 & 8 & 13.6 & 6 & 10.2 & 15 & 25.4 & 12 & 20 \\
\hline$\geq 35$ & 31 & 2 & 6.5 & 5 & 16.1 & 11 & 35.5 & 11 & 35.5 \\
\hline
\end{tabular}

Gender

$\begin{array}{lrrrrrrrrr}\text { female } & 134 & 7 & 5.2 & 12 & 9.0 & 30 & 22.4 & 27 & 20.1 \\ \text { male/transgender } & 13 & 6 & 46.2^{*} & 1 & 7.7 & 4 & 30.8 & 2 & 15.4\end{array}$

Skin color

$\begin{array}{lrrrrrrrrr}\text { white } & 104 & 8 & 7.7 & 8 & 7.7 & 19 & 18.3 & 21 & 20.2 \\ \text { non white } & 43 & 5 & 11.6 & 5 & 11.6 & 15 & 34.9 * & 8 & 18.6\end{array}$

Schooling (years)

$\begin{array}{rrrrrrrrrr}0-7 & 91 & 8 & 8.8 & 10 & 1.0 & 24 & 26.4 & 25 & 27.5^{*} \\ \geq 8 & 56 & 5 & 8.9 & 3 & 5.4 & 10 & 17.9 & 4 & 7.1\end{array}$

Prostitution (months)

$\begin{array}{rrrrrrrrrr}0-60 & 99 & 4 & 4.0 & 7 & 7.1 & 17 & 17.2 & 16 & 16.2 \\ \geq 61 & 48 & 9 & 18.8^{*} & 6 & 12.5 & 17 & 35.4^{*} & 13 & 27.1\end{array}$

Condom use

$\begin{array}{lrrrrrrrrr}\text { yes } & 63 & 4 & 6.3 & 4 & 6.3 & 14 & 22.2 & 13 & 20.6 \\ \text { no } & 84 & 9 & 10.7 & 9 & 10.7 & 20 & 23.8 & 16 & 19.0\end{array}$

Sexual intercourse/day

$\begin{array}{lrrrrrrrrr}0-2 & 82 & 3 & 3.7 & 6 & 7.3 & 16 & 19.5 & 13 & 15.9 \\ \geq 3 & 65 & 10 & 15.4^{*} & 7 & 10.8 & 18 & 27.7 & 16 & 24.6\end{array}$

Anal sex

$\begin{array}{lrrrrrrrrr}\text { yes } & 42 & 8 & 19.0^{*} & 5 & 11.9 & 10 & 23.8 & 10 & 23.8 \\ \text { no } & 105 & 5 & 4.8 & 8 & 7.6 & 24 & 22.9 & 19 & 18.1\end{array}$

History of STD

$\begin{array}{lrrrrrrrrr}\text { yes } & 80 & 8 & 10.0 & 7 & 8.8 & 16 & 20.0 & 19 & 23.8 \\ \text { no } & 67 & 5 & 7.5 & 6 & 9.0 & 18 & 26.9 & 10 & 14.9\end{array}$

Drug use

$\begin{array}{lrrrrrrrrr}\text { yes } & 83 & 10 & 12.0 & 7 & 8.4 & 18 & 21.7 & 15 & 18.1 \\ \text { no } & 64 & 3 & 4.7 & 6 & 9.4 & 16 & 25.0 & 14 & 21.9\end{array}$

Alcohol use

$\begin{array}{lrrrrrrrrrr}\text { yes } & 123 & 8 & 6.5 & 9 & 7.3 & 28 & 22.8 & 22 & 17.9 \\ \text { no } & 24 & 5 & 20.8^{*} & 4 & 16.7 & 6 & 25.0 & 7 & 29.2\end{array}$

${ }^{*} \mathrm{p}<0.05$; Chi-square test or Fisher's exact test. HIV: human immunodeficiency virus; HCV: hepatitis C virus; HBV: hepatitis B virus; STD: sexually transmitted diseases; HBV+§: Hepatitis B virus active or past infection (HBsAg+, anti-HBc total+, or both); HBsAg: hepatitis B surface antigen; anti-HBc: anti-hepatitis B core total. 
anal intercourse. Although not statistically significant, there was a higher percentage of infection among SWs who did not use condoms than those who did. These aspects have also been demonstrated by Carter et al., who found a $25 \%$ seroprevalence of HIV infection in 108 SWs, which was associated with unprotected sex, use of illicit drugs such as cocaine, and more than 5 clients per week ${ }^{11}$. A recent Brazilian study on risky practices for HIV infection among female SWs in 10 Brazilian cities found that the length of time in prostitution, low price charged for sexual services, association with other STDs such as syphilis, and unprotected sex were the main factors associated with HIV infection in this group ${ }^{12}$. There was a high prevalence of HBV infection among non-white SWs and among those with a longer time in prostitution.

Regarding the high frequency of HIV infection among men and the practice of anal sex, it is known that anal sex can cause damage to the rectal mucosa, producing increased risk of acquiring infection ${ }^{13}$. There was a high prevalence of $\mathrm{HCV}$ infection among those who had anal sex, although sexual transmission of $\mathrm{HCV}$ in general is low. In this study, $21.6 \%$ of female SWs also reported anal sex, and risk of HIV transmission is higher in anal sex than vaginal intercourse ${ }^{14}$.

The use of injecting drugs was not a common practice according to the study participants. The use of inhaled illicit drugs (56.5\%) and alcohol consumption (83.7\%) was common among respondents. Drug and alcohol abuse leads to increased risk of HIV infection because it is reported in association with poor adherence to condom use, greater numbers of casual partners, group sex, and anal intercourse. There was a high prevalence of $\mathrm{HCV}$ infection among inhaling drug users.

In this study, $19.7 \%$ of participants had positive serology for syphilis, which is higher than the 3.8\% syphilis prevalence reported in a survey conducted among SWs by the Brazilian Ministry of Health ${ }^{2}$. Because it is an ulcerative STI, syphilis carries an additional risk for HIV and other STDs ${ }^{11}$, as confirmed in this study, wherein $30.8 \%$ of the HIV-infected individuals had also had syphilis. Some studies indicate syphilis as a risk factor/marker for HIV infection.

As for condom use, $53.1 \%$ reported occasional unprotected sex with clients and steady partners. In a survey conducted by the Brazilian Ministry of Health, $32.8 \%$ of female SWs reported unprotected vaginal sex, and there was little adherence to condom use in anal intercourse $(42 \%)$ or oral sex $(32 \%)^{15}$.

The limitations of this study included the cross-sectional format, which prevented the assessment of risk factors since exposure and outcome are measured at the same time. In addition, data collection through interviews does not guarantee the reliability of all responses, particularly those related to behavioral aspects of drug abuse and condom use. The small number of male SWs who participated prevented a more complex comparative analysis between men and women. Because the participants were selected on a convenience sample basis, and the representativeness of the sample size could not be established, the external validity of this study is impaired. However, it should be highlighted that access to this population for serological testing is very difficult, and the findings are relevant to public health.

We conclude that SWs have high prevalence of HIV infection and coinfection with viral hepatitis and syphilis, as well as several factors associated with vulnerability to STDs. The infection rates recorded in this study are higher than those found in the general population and in other studies involving SWs.

\section{ACKNOWLEDGMENTS}

We thank the Municipal Health Departments of Tubarão, Laguna, and Imbituba for the technical support, and for referring the positive cases for confirmation and assistance by a multidisciplinary team. We gratefully thank the Indústria da Solidariedade and Arte Positiva NGOs for logistical support in data collection. We also thank the Health Department of the State of São Paulo, and the Emilio Ribas Institute. We thank especially Dr. Marcos Vinicius da Silva, infectious disease expert, who offered assistance performing serological tests for hepatitis and syphilis. This article was translated by Wicfast consult.

\section{CONFLICT OF INTEREST}

The authors declare that there is no conflict of interest.

\section{FINANCIAL SUPPORT}

This study was conducted with a research grant from the Merit Award Program of the University Foundation for Support of Scientific and Technological Research of the State of Santa Catarina - FAPESC.

\section{REFERENCES}

1. Greco DB. A epidemia da AIDS: impacto social, científico, econômico e perspectivas Estud Av 2008; 22:73-94.

2. Ministério da Saúde. Programa nacional de DST/AIDS. Boletim Epidemiológico AIDS DST - Ano VII n.1. $27^{\mathrm{a}}$ a $52^{\mathrm{a}}$ semanas epidemiológicas - julho a dezembro de 2009; $1^{\mathrm{a}}$ a $26^{\mathrm{a}}$ semanas epidemiológicas - janeiro a junho 2010. [Cited 2011 July 15]. Available from: www.AIDS.gov.br/.

3. Chen JJ, Yu CB, Du WB, Li LJ. Prevalence of hepatitis B and C in HIV-infected patients: a meta-analysis. Hepatobiliary Pancreat Dis Int 2011; 10:122-127.

4. Pando MA, Bernini C, Binini M, Fernandez M, Reinaga E, Maulen S, et al. Prevalence of HIV and ther Sexuality Transmitted Infections Among Female Commercial Sex Workers in Argentina. Am J Trop Med Hyg 2006; 74:233-238.

5. Bueno SMV, Mamede MV. Comportamento das profissionais do sexo: relacionado a DSTs e AIDS. J Bras Doenças Sex Trans 1997; 9:4-9.

6. Trevisol FS, Silva MV. HIV Frequency Among Female Sex Workers in Imbituba, Santa Catarina, Brazil. BJID 2005; 9:500-505.

7. Andrade Neto JL. Epidemiologia da Síndrome da Imunodeficiência Adquirida em prostitutas [Dissertation]. [Curitiba (PR)]: Universidade Federal do Paraná; 1993. $132 \mathrm{p}$.

8. Paiva Vera, Pupo LR, Barboza R. O direito a prevenção e os desafios da redução da vulnerabilidade ao HIV no Brasil. Rev Saude Publica 2006; 40 (supl): 109-119.

9. Russi JC, Serra M, Viñoles J, Pérez MT, Ruchansky D, Alonso D, et al. Sexual transmission of hepatitis B virus, hepatitis B virus and human immunodeficiency virus type 1 infections among male transvestite comercial sex workers in Montevideo, Uruguay. Am J Med Hyg 2003; 68:716-720.

10. Oliveira CSF, Silva AV, Santos KN, Fecury AA, Almeida MKC, Fernandes AP, et al. Hepatitis $\mathrm{B}$ and $\mathrm{C}$ vírus infection among Brazilian Amazon riparians. Rev Soc Bras Med Trop 2011; 44:546-550.

11. Carter KH, Harry BP, Jeune M, Nicholson D. Percepción del riesgo, comportamientos riesgosos y seroprevalencia del VIH en trabajadoras sexuales de Georgetown, Guyana. Rev Panm Salud Publica 1997; 1:451-459. 
12. Damacena GN, Szwarcwald CL, Souza Júnior PR, Dourado I. Risk Factors Associated With HIV Prevalence Among Female Sex Workers in 10 Brazilian Cities. J Acquir Immune Defic Syndr 2011; 57 (supl III):144-152.

13. Mustanski BS, Newcomb ME, Du Bois SN, Garcia SC, Grov C. HIV in young men who have sex with men: a review of epidemiology, risk and protective factors, and interventions. J Sex Res 2011; 48:218-253.
14. Jenness SM, Begier EM, Neaigus A, Murril CS, Wendel T, Hagan H. Unprotected anal intercourse and sexually transmitted diseases in high-risk heterosexual women. Am J Public Health 2011; 101:745-750.

15. Ministério da Saúde. Avaliação da efetividade das ações de prevenção dirigidas às profissionais do sexo, em três Regiões Brasileiras. Brasília: Secretaria Executiva. Coordenação Nacional de DST/AIDS. Ministério da Saúde; 2003. 